\title{
Decision Making Of Suitable Bioenergy Power Plant Location: A Case Study
}

\author{
Muhammed Sutcu ${ }^{1}$, Fatih Yasin Güner ${ }^{2}$, Ramazan Duran $^{3}$, İsmet Söylemez ${ }^{4} *$ \\ ${ }^{1}$ Asiss. Prof., Department of Industrial Engineering, Abdullah Gül University \\ ${ }^{2}$ Department of Industrial Engineering, Abdullah Gül University \\ ${ }^{3}$ Department of Industrial Engineering, Abdullah Gül University \\ ${ }^{4}$ Dr., Department of Industrial Engineering, Abdullah Gül University \\ 1'muhammed.sutcu@agu.edu.tr, ${ }^{2}$ fatihyasin.guner@agu.edu.tr, ${ }^{3}$ ramazan.duran@agu.edu.tr, ${ }^{4}$ ismet.soylemez@agu.edu.tr \\ *Corresponding Author
}

\begin{abstract}
Selection of an appropriate place for biomass power plant is very essential, balance of transported amount and collected amount should be in a balance. Otherwise, transportation cost is going to cause huge loss of profits. According to references that referred in literature review, to determine appropriate places for biomass power plant, facility location problem have applied. This research addresses Facility Location Problem and then Mixed Integer Programming Model is developed which maximizes the potential value of facilities is going to be built. That model is used for solving different size of problems such as number of cities that is going to be selected and transportation budget. After 21 different size of the model is solved, the solution is compared and ideal solution trying to be elected. Therefore, the case of electing 3 cities or 5 cities should have 3 billion budget and 7 city electing should have 5 billion budget with respect to regression trend line. For this purpose, the logistics on Turkey, biomass potential and cost in mind, the most appropriate location and the type of bioenergy plants should be selected in this study.
\end{abstract}

Index Terms-Biomass, Renewable energy, Optimization, power plant selection.

\section{INTRODUCTION}

$\mathrm{B}$ IOENERGY is one of the renewable energy types which is obtained from biological resources. Although bioenergy is used frequently, amount of energy that obtained from a bioenergy power plant in Turkey is considerably low. According to Y1lmaz [1], there are 73 active bioenergy power plants in Turkey. Additionally, the biggest power plant in İstanbul which is Odayeri has $33.81 \mathrm{MWe}$ installed capacity which is less than $1 / 20$ capacity of the biggest bioenergy power plant in the world. The biggest power plant is Ironbridge and it has capacity of $740 \mathrm{MW}$.

The total biomass energy potential in Turkey shows that approximately 33 million tons of oil equivalent. When viewed biomass potential in Turkey seems to be very large. Based on this situation, existing facilities continue producing electricity and also new facilities should be opened in the most efficient way. For this purpose, the logistics on Turkey, biomass potential and cost in mind, the most appropriate location and the type of bioenergy plants should be selected [2].

\section{LITERATURE REVIEW}

Decision-making methods and applications for bioenergy systems are classified [3]. Additionally, authors keep an account of methods that used for bioenergy problems. That gives brief introduction to method and problem mapping. De Mol [4] define simulation and optimization models can be used for cost estimation. On the one hand, output of the simulation model can be throughput of biomass, cost, energy consumption and number of transportations. On the other hand, optimization model especially used for selection of site of energy plant. Fiedler et al. [12] describe variety of biomass supply and main objectives in planning of supply systems. Additionally, elements of supply system and the fundamentals of decision making in supply logistics are emphasized.

The logistical challenges in the supply of biomass to a bio-refinery are analyzed [5]. They have also developed a mathematical model that can be used to design the supply chain and manage a bio-finery logistics. Supply chain design decisions are long-term decisions; As logistics management has medium and short term decisions, they want to help coordinate these decisions with the proposed model. The model helps determine the number, location and size of refineries required to produce biofuels using biomass. They also wanted to determine the amount of biomass delivered, processed and stocked over a period of time in the model. In the model, biomass raw material, biomass transport, inventory and processing costs are given as input. Bowling et al. tried to provide a systematic approach for optimal production planning and plant layout of a bio refinery [6]. First, a representation has been developed to include biomass raw material, pre-treatment centers and central processing plants to produce the desired products and by-products. A mathematical model was then developed to determine the most appropriate supply chain, size, operational strategies and location to be installed in the bio refinery and pre-treatment center facilities. The model determined the maximum net profit. To this end, it has made it possible to consider the optimum selection of different components at the same time, taking into account the specific location configuration, biomass selection and processing facilities. The purpose of 
this model is to increase profits by taking into account the general sales and the costs of raw materials, transportation costs, capital costs of the facilities and operating costs of the facilities. The model also used convex relationships to guarantee an optimal global solution. The supply chain planning of biomass in Thailand are considered [7]. The aim of this study is to establish a planning system for biomass plant location selection and biomass allocation to each plant. The three components of the biomass supply chain are considered as suppliers, bio-power plants and customers. A mathematical model has been developed with a mixed-integer linear programming in order to determine the amount of biomass that should always be ordered from different suppliers of the period and taking into account the constraints on bio-power plants. The aim of the model is to minimize the total cost by considering the four cost components, including the fixed opening of the proposed bioelectric power plants, the cost of materials resulting from the purchase of biomass, the transportation cost between suppliers and bioelectric power plants and the cost of holding stock.

The international forest biomass has said that it is considered a valuable renewable energy raw material, but the use of forest residues is difficult, it has been shown that factors related to collection, processing and transport impose restrictions on the economic viability of residue handling processes and affect their supply from dispersed raw material locations [8]. They said that it is very important to take into account these supply chain issues in order to optimize decision-making on suitable locations for biomass power plants that want to use forest residues. In this article, work has been conducted in Australia and Tasmania and presents a research for the integration of Multi-Criteria analysis (MCA) and Geographic Information systems (GIS) to identify the most suitable locations for potential biomass power plants. The amount of forest harvest biomass residues was estimated in Tasmania (NIPNF) according to a non-industrial private natural resource model. The integration of a GIS model, including MCA and a supply chain cost analysis, attempted to identify and analyze the most appropriate locations that attempt to balance economic, environmental and social criteria within biomass supply. Jeong and Ramírez-Gómez [9] are stated that determining the correct location of a biomass plant is a critical issue due to its geographically characteristic biomass materials. The article said that a GIS-MCDA approach and sensitivity analysis should be performed with WLC to optimize the appropriate areas of a biomass plant. It has demonstrated that this approach can be used to solve renewable energy planning problems in the context of a sustainable environment. The results have not shown that the most appropriate places and products can be used as a recommendation for governments in countries and can be used in decision making for renewable energy management policy. McKendry [10] mentioned that the use of renewable energy sources is becoming increasingly necessary. Biomass is a renewable energy source that is widely used in the third world, but has been used less recently in the Western world. He recently mentioned that there has been a focus on identifying suitable biomass species that can provide high-energy outputs instead of fossil fuels.

Román and Paneque [11] mentioned that biomass is now used for energy purposes such as heat and electricity generation. Potential raw materials are wheat, oats and barley straw, corn stock from the agricultural industry and wood waste from the wood industry and sawdust from the wood industry. The most suitable place to establish an energy production facility, distance from villages, energy demands, industrial location and so on. it was determined according to various conditions. A proposal has been created for optimal location and installation. A total of 19 regions that meet the requirements for the three scenarios are specified as eligible locations.

\section{PROPOSED WORK}

Currently, in each city biomass can be reached up to the same amount. Additionally, this amount can be increased with biomass that supplied from neighbor cities in return for transportation cost. Collected biomass amount is equivalent to potential electrical energy which is going to be used for biomass power plant. Selection of a place for biomass power plant is very essential, balance of transported amount and collected amount should be in a balance. Otherwise, transportation cost is going to cause huge loss of profits. According to references that referred in literature review, to determine appropriate places for biomass power plant, facility location problem have used. Data which is taken from BEPA and will be used for model, kept as TEP (Ton equivalent oil)/Year. However, this unit is not useful to make calculation for determining capacity of power plant. Therefore, that value is converted into $\mathrm{mWh}$ with formula that given below.

$(T E P /$ year $) * 11600 * 365 / 24 / 10 / 1000 / \mathrm{n} ; 11600$ is used for converting TEP to $\mathrm{kWh} 365$ is used for converting Year to Day; 24 is used for converting Day to Hour; 10 is used for efficiency ratio of burning biomass $(10 \%) ; 1000$ is used for converting $\mathrm{kWh}$ to mwah; $\mathrm{n}$ stands for number of facilities that shares all potential energy

In this model, each city of Turkey is assigned as a candidate city for biomass power plant. Cities are paying very little price to use biomass in the same city. However, for the different cities, transportation cost is directly affected by distance between cities. Transportation amount is limited by transportation cost. With different transportation cost limitations and number of facilities size of the model is differentiated.

\section{A. Mathematical model}

Our Facility Location Problem is formulated as the following in order to obtain maximizing the potential energy of all facilities that is going to be built with given amount of transportation cost and number of facilities that is going to be used. 
$\underline{\text { Index }}$

$\mathrm{i}, j:$ the index of city

$\mathrm{n}$ : number of city

\section{$\underline{\text { Parameters }}$}

$\mathrm{A}_{i}$ : amount of biomass in city $\mathrm{i}$

$\mathrm{R}_{i}$ : the ratio of amount and potential energy in city $\mathrm{i}$

$D:$ the distance between city $i$ and $j$

TRij : transportation cost

$\operatorname{Tr} \mathrm{s} B \mathrm{~d}$ : transportation cost budget

EN : minimum amount of energy needed

maxdis : maximum distance of city that can be supplier

FA: the number of facilities which is going to be selected

$T C$ : Amount of 100 tons that truck can deliver

Decision Variables

$\mathrm{X} i$ : Whether the facility is opened in city $\mathrm{i}$ or not

$Y i j$ : Whether the biomass is supplied from city $j$ to city $\mathrm{i}$

Tij : Amount of transported biomass from $j$ to $i$

\section{Objective Function}

$$
\begin{gathered}
\max _{z}=\sum_{i} \sum_{j} R_{j} * T_{i j} \\
\sum_{i \in n} X_{i}=F A \\
X_{i}-Y_{i j} \geq 0 \forall i, j \\
T R_{i j} / D_{i j} \leq A_{j} \forall i, j \\
Y_{i j} * D_{i j}-\operatorname{maxdis} \leq 0 \forall i, j \\
\sum_{i} \sum_{j} A_{j} * D_{i j} * T C a p * C * Y_{i j} \leq \operatorname{TrsBd} \\
\sum_{i} T_{i j} \leq A_{j} \forall j \\
X_{i}, Y_{i j} \in\{0,1\} \forall i, j \\
T_{i j} \geq 0 \forall i, j
\end{gathered}
$$

Objective function represents that model aims to maximize potential energy of facilities. Constraint (2) represents that number of opened facilities should be equal to how much facilities going to be opened. Constraint (3) guarantees that if facility is not opened in a city, nothing is going to be transported to that city. Constraint (4) represents that if there is no transfer between two cities transferred amount should be 0 . Constraint (5) guarantees that two cities that make transfer between each other cannot be further than maximum distance. Constraint (6) guarantees that total transportation cost cannot exceed transportation budget. Constraint (7) represents that total transferred amount cannot be more than amount in the city.

\section{NumericAl Results}

As shown in the following figures, these are different solutions that received from GAMS software for different size of the problems. It appears that for different size of problems solution diversifies.

Solution with selecting 3 cities are finalizes at 3 billion budget and selecting Balıkesir, Aksaray, Osmaniye. Solution with selecting 5 cities finalises at 5 billion budget and selecting Balıkesir, Çorum, Diyarbakır, Aksaray, Osmaniye. Solution with selecting 7 cities selects Aydın, Bursa, Çorum, Diyarbakır, Tekirdağ, Aksaray, Osmaniye at 7 billion budget. Potential energy of each facility is given at Table 4. 7 Cities has huge superiority against other number of city selections in terms of total potential energy.

\section{TABLE 1. CITIES THAT ELECTED FOR 3 CITY PROBLEM}

\begin{tabular}{|l|l|l|l|}
\cline { 2 - 4 } \multicolumn{1}{c|}{} & \multicolumn{3}{c|}{3 Cities } \\
\hline Budget & 1 & 2 & 3 \\
\hline 100000000 & Adana & Tekirdağ & Karaman \\
\hline 500000000 & Adana & İzmir & Konya \\
\hline 1000000000 & Adana & İzmir & Konya \\
\hline 1500000000 & Adana & Konya & Maraș \\
\hline 3000000000 & Balıkesir & Aksaray & Osmaniye \\
\hline 5000000000 & Balıkesir & Aksaray & Osmaniye \\
\hline 7000000000 & Balıkesir & Aksaray & Osmaniye \\
\hline
\end{tabular}

\section{COnClusion And Future SCOPE}

To sum up, this research addresses Facility Location Problem and then Mixed Integer Programming Model is developed which maximizes the potential value of facilities is

TABLE 2. CITIES THAT ELECTED FOR 5 CITY PROBLEM

\begin{tabular}{|l|l|l|l|l|l|}
\hline & \multicolumn{5}{|c|}{5 Cities } \\
\hline Budget & 1 & 2 & 3 & 4 & 5 \\
\hline 100000000 & Adana & Edirne & Tekirdağ & Karaman & Osmaniye \\
\hline 500000000 & Adana & İzmir & Konya & Samsun & Șanlıurfa \\
\hline 1000000000 & Adana & İzmir & Kırklareli & Konya & Șanlıurfa \\
\hline 1500000000 & Adana & Balıkesir & İzmir & Kırklareli & Konya \\
\hline 3000000000 & Aydın & Balıkesir & İzmir & Konya & Maraș \\
\hline 5000000000 & Balıkesir & Çorum & Diyarbakır & Aksaray & Osmaniye \\
\hline 7000000000 & Balıkesir & Corum & Diyarbakır & Aksaray & Osmaniye \\
\hline
\end{tabular}


TABLE 3. CiTIES THAT ELECTED FOR 7 CITY PROBLEM

\begin{tabular}{|l|l|l|l|l|l|l|l|}
\hline & \multicolumn{7}{|c|}{7 Cities } \\
\hline Budget & 1 & 2 & 3 & 4 & 5 & 6 & 7 \\
\hline 100000000 & Adana & Amasya & Samsun & Tekirdağ & Karaman & Bartın & Osmaniye \\
\hline 500000000 & Adana & Bursa & İzmir & Konya & Samsun & Tekirdağ & Șanlıurfa \\
\hline 1000000000 & Adana & Balıkesir & İzmir & Kırklareli & Konya & Samsun & Șanlıurfa \\
\hline 1500000000 & Adana & Balıkesir & İzmir & Kırklareli & Konya & Samsun & Șanlıurfa \\
\hline 3000000000 & Adana & Amasya & Balıkesir & Diyarbakır & İzmir & Kırklareli & Konya \\
\hline 5000000000 & Adana & Aydın & Bursa & Ccorum & Tekirdağ & Șanlıurfa & Aksaray \\
\hline 7000000000 & Aydın & Bursa & Corum & Diyarbakır & Tekirdağ & Aksaray & Osmaniye \\
\hline
\end{tabular}

going to be built. That model is used for solving different size of problems such as number of cities that is going to be selected and transportation budget. After 21 different size of the model is solved, the solution is compared and ideal solution trying to be elected. Therefore, the case of electing 3 cities or 5 cities should have 3 billion budget and 7 city electing should have 5 billion budget with respect to regression trendline.

In case of selecting 3 city with 3 billion budget, Balikesir, Aksaray and Osmaniye should be selected. In case of selecting 5 city with 3 billion budget Aydın, Balıkesir, İzmir, Konya and Maraş should be selected. Finally, In case of selecting 7 city with 5 billion budget, Adana, Aydın, Bursa, Çorum, Tekirdağ, Şanlıurfa and Aksaray should be selected.

TABLE 4. POTENTIAL ENERGY OF EACH FACILITY

\begin{tabular}{|l|l|l|l|}
\hline & 3 Cities & 5 Cities & 7 Cities \\
\hline 100000000 & 343,7228752 & 300,0228 & 263,3946 \\
\hline 500000000 & 485,2312222 & 398,46 & 348,0576 \\
\hline 1000000000 & 569,5719178 & 469,3959 & 404,8532 \\
\hline 1500000000 & 670,6477763 & 530,5549 & 448,4914 \\
\hline 3000000000 & 845,3846499 & 690,7695 & 579,8774 \\
\hline 5000000000 & 845,3846499 & 795,6892 & 718,3078 \\
\hline 7000000000 & 845,3846499 & 795,6892 & 746,0887 \\
\hline
\end{tabular}

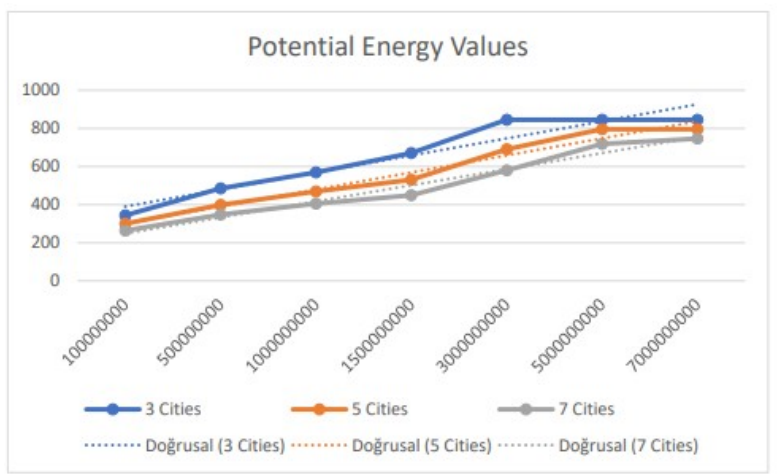

Figure 1. The objective function values of each solution
Figure 1 shows the objective function values of each solution. After 5 billion, it is very challenging to improve current solution.

\section{REFERENCES:}

[1] Yılmaz, A., Ünvar, S., Koca, T.and Koçer, A., (2017). Türkiye"de Biyogaz Üretimi ve Biyogaz Üretimi İstatistik Bilgileri, Technological Applied Sciences (NWSATAS), 12(4):218-232.

[2] Toklu E., (2017). Biomass energy potential and utilization in Turkey, Renevable Energy: 235-244.

[3] Scott, J.A., Ho, W. and Dey, P. K., (2012). A Review of MultiCriteria Decision Making Methods for Bioenergy Systems. Energy. 42(1):146-156.

[4] De Mol, R. M., Jogems, M. A. H., Van Beek, P. and Gigler, J. K., (1997). Simulation and Optimization of the Logistics of Biomass Fuel Collection. Netherlands Journal of Agricultural Science 45: 219-228.

[5] Ekșioğlu, S. D., Acharya, A., Leightley, L. E., and Arora, S. (2009). Analyzing the design and management of biomass-to-biorefinery supply chain. Computers and Industrial Engineering, 57(4), 13421352.

[6] Bowling, I. M., Ponce-Ortega José María, and El-Halwagi, M. M. (2011). Facility Location and Supply Chain Optimization for a Biorefinery. Industrial and Engineering Chemistry Research, 50(10), 6276-6286.

[7] Patomtummakan J. and Nananukul N. (2018). Biomass Power Plant Location and Distribution Planning System. GMSARN Int. J., 12, $11-18$.

[8] Woo, H., Acuna, M., Moroni, M., Taskhiri, M., and Turner, P. (2018). Optimizing the Location of Biomass Energy Facilities by Integrating Multi-Criteria Analysis (MCA) and Geographical Information Systems (GIS). Forests, 9(10), 585.

[9] Jeong, J. S., and Ramírez-Gómez, Á. (2017). Renewable energy management to identify suitable biomass facility location with GISbased assessment for sustainable environment. Energy Procedia, 136, 139-144.

[10] Mckendry, P. (2002). Energy production from biomass (part 1): overview of biomass. Bioresource Technology, 83(1), 37-46.

[11] Román-Figueroa, C., Herrera, S., and Paneque, M. (2019). Selection of Optimal Localization for a Biomass Energy Plant that Uses Residual Biomass as a Raw 15 Material in the Araucanía Region of Chile. Biomass for Bioenergy - Recent Trends and Future Challenges. DOI: 10.5772 /intechopen. 83526 .

[12] Fiedler, P., Lange, M., and Schultze, M. (2007, September). Supply logistics for the industrialized use of biomass-principles and planning approach. In 2007 International Symposium on Logistics and Industrial Informatics, 41-46. 